\title{
Validity and Reliability of the Management Communication Style Scale
}

\author{
Abdul Aziz Rozilah, Mokhtar Muhammad, and Norlida Kamaluddin
}

\begin{abstract}
Communication is a vehicle and central element in an organization as it and serves many functions in organization. What people in the organization say has a meaningful impact on the total system of the organization. Encouraging subordinates to communicate and participate in decision-making not only can promote commitment among the subordinates, but also increase job satisfaction among people who interact and work interdependently. Based on this belief, this quantitative study was to systematically develop a reliable and valid construct that can facilitate and enhance the different Management Communication Style (MCS) in the Malaysian context. Four dimensions of MCS namely Tell, Sell, Consult and Join were identified through an extensive literature review by following Hinkin's suggestions for construct development. A survey questionnaire was administered to 388 executives working directly under Human Resource Managers in the state-owned organization known as Government Link Companies (GLCs). A confirmatory factor analysis (CFA) was initially conducted on 20 items to explore the structure underlying the set of questions designed. The results of CFA confirmed that the measurement scale used in this study satisfactorily met the standard of validity and reliability analyses. The MCS construct provides a multi-dimensional assessment tool to diagnose and guide organizational communication.
\end{abstract}

Index Terms-Management communication style, leadership style, communication, decision-making.

\section{INTRODUCTION}

MCS of a supervisor within an organization is a function of both the management style imposed on the supervisor by the organization (or chosen by the supervisor within the parameters permitted by the organization) and the communication style of the individual supervisor which that individual brings to the organizational context [1]. The MCS of managers in an organization has evidenced to influence the level of employees' satisfaction and circumvent conflict at the workplace. MCS is directly and meaningfully linked to employees' satisfaction [2]. Managers who exercise more employee centered and interactive MCS would increase satisfaction among employees and vice versa [2]. According to Richmond and McCroskey [3], employees' satisfaction could be directly varied by altering the management style of the organization or selection of a supervisor with a differing communication style. Numorous researchers that have examined elements in the working environment agreed that, communication between supervisors and subordinates and inviting them to participate in decision-making process has

Manuscript received April 5, 2013; revised June 5, 2013.

The authors are with the Faculty of Business Management, Universiti Teknologi MARA, Bandar Puncak Alam, Selangor, Malaysia (e-mail: rozilah@puncakalam.uitm.edu.my, Mokhtar413@salam.uitm.edu.my, norlidak@salam.uitm.edu.my). been found to increase employees' satisfaction [4].

Central to the MCS development, the dimensions and the operationalization of MCS was constructed by Richmond and McCroskey [5]. The instrument was originated from the work of Tannenbaum and Schmidt [6] and the research of Sadler [7], where Tannenbaum and Schmidt [6] postulate a continuum of leadership orientations within an organization from the extreme "boss centered" to the extreme "subordinated centered." It describes that as a leaser moves from the first extreme to the latter, the use of authority by the manager decreases and the freedom for subordinate increases. Tannenbaum and Schmidt [6] and Sadler [7] also provide a continuum for leadership and involvement that includes an increasing role for employees and a decreasing role for supervisors in the decision process. Although the original conceptualization by the earliest theorists [6], [7] envisioned seven stem along the continuum, Richmond and McCroskey [5] had removed apparently overlapping steps of the continuum and formed a four-step continuum labeled: Tell, Sell, Consul, and Join. The four continuum of MCS includes Tell (manager makes decisions (or receive them from top level management) and announces them to subordinates). Sell: (manager receives decision from the above and is given a little bit of authority to make decisions). Consult: (manager invites subordinates input into a decision while retaining authority to make the final decision herself). Join: (manager usually does not make decision rather the authority to make the decisions is delegated to the subordinates, either in cooperation with the manager or in her or his absence [5]. An examination of these approaches explicitly assumed that relationship between leadership or management style and communication style. Obviously, if all decisions are made by the top management, managers can only decide to use a Tell and Style styles which restrict the communication styles available for use. Conversely if manages are given a great deal of autonomy, suggesting a consult or joint style, they have great flexibility in selecting MCS for interface with employees [4].

Even though, Richmond and McCroskey [5] have systematically developed a valid and reliable 19-point continuum ranging from Tell (1-10), through Sell (11-16), through Consult (17-22), and to Join (23-28), the items were not highlighted. The subjects were simply asked to circle the MCS under which they are working. The scale allowed subjects to record position on the continuum that represent a mixture of MCS [5]. Despite a number of theoretical models describing the degrees of "freedom" that managers grant employees during decision-making and the "communication style" used in decision making, there is still a lack of a clear picture of the forces biasing managers' use of MCS in Malaysia [8]. Though communication scholars had published articles presenting various views about the nature and the 
importance of communication and participation in decision-making, very few were attempted to develop a measure of MCS using likert scale. Hence the focus of this study was on the developing of a systematic, reliable and valid measure of an organization's capacity for MCS. Furthermore, considering the importance of the MCS construct, the inherent difficulties in its definition and quantification, and dearth study on MCS in Malaysia, it warrants an intensive research on the MCS construct that is suitable and applicable to the Malaysian organizational climate. Based on the gap, the concept of MCS was developed in order to examine the role of leadership style and communication in decision-making in the organizational context, as well as to evaluate the strategies uses by the managers to generate positive outcomes in organization. Explicating traits biasing managers' predilection for employee participation, and communication used are essential to deepen the understanding of MCS and provide more complete models describing when and why different type of MCS is utilized or avoided in contemporary organizational context. The MCS construct provides a multi-dimensional assessment tool to diagnose and guide organizational communication.

\section{HINKIN'S SCALE DEVLOPMENT CONSTRUCTION}

Hinkin [9], [10] highlighted that to satisfactory operationalize a construct with appropriate measures and determine construct validity the best practice scale development follows three basic stages: Item generation, scale development, and scale evaluation.

\section{A. Item Generation}

The primary step to develop a new organizational scale is to achieve a thorough item generation: deductive and inductive [10]: In deductive approaches an understanding of the MCS was investigated by reviewing thoroughly the literature to develop theoretical definition of the construct. The definition is then used as a guide for the development of 30 items in MCS. Inductive approaches were conducted by interviewing six (6) Human Resource Managers (HR Managers) and six (6) employees from the GLCs to obtain ideas and opinion of some aspect of behavior towards MCS from them. From the deductive and inductive process, 35 items were generated. The items were then distributed to the same HR Managers and employees for their further comments and opinion. This process served as a pretest where items that were deemed to be conceptually inconsistent are deleted, and items that conceptually consistent remained. After the deletion process 25 items were generated as MCS scale.

\section{B. Scale Development}

The second stage of scale development was performed by focusing on the designing a development study, scale construction, and reliability assessment. Adequate internal consistency reliability was obtained with as few as five items [10]. Hinkin [9] reported that an adequate internal consistency reliabilities can be obtained with as few as three items. Items were rated on a 6 point - Likert scale: (6) strongly agree, (5) agree, (4) moderately agree (3) moderately disagree (2), disagree, (1) strongly disagree was used to generate sufficient variance among respondents for subsequent statistical analysis. A sample size of 101 employees working directly under HR Managers was used as a pilot study to analyze the data. An exploratory factor analysis (EFA) was conducted to test the validity and reliability of the new instrument constructed. The EFA analysis has confirmed the four dimensions of MCS namely Tell, Sell, Consult, and Join. Consequently, a sample size of 388 of employees working under HR Managers was used to appropriately conduct test of statistical significance. If powerful statistical tests and confidence in results are desired, a larger sample is better and the likelihood of attaining statistical increases [11]. Confirmatory factor analysis (CFA) was conducted to assess the quality of the factor structure by statistically testing the significance of the overall model and of item loadings on factors [12]. The purpose of the analysis is to assess the goodness-of-fit of the new measure constructs. Overall, the EFA and CFA purposes of this study were conducted to examine the stability of the factor structure and provide information that would facilitate the refinement of a new MCS measure. EFA analysis allows the elimination of obviously poorly loading items [13] and CFA allows more precision in evaluating the measurement model [14].

Subsequently, a scale development which includes an assessment of the psychometric properties of the scale was constructed. It is necessary to administer the potential items to a representative sample in order to examine how well the items confirm expectations related to the structure of the measure in question [15]. The scale has been consistently administered and the psychometric properties of this scale have been highly reliable.

\section{Scale Evaluation}

Content validity: Content validity refers to the extent to which a measure represents all facets of a given social concept [16]. Content validity signifies that the items included in the questionnaire correctly represent the concept to be analyzed [17] and evaluated based on logic and theory [18] rather than statistical. In this study MCS scale was validated by two experts in organizational communication field and one expert in GLCs. At this stage, two items were improved and five items were deleted as recommended by the three experts.

Construct validity (Factor Analysis): Construct validity refers to whether a scale measures or correlates with a theorized psychological construct [18]. The EFA with Varimax rotation was used to assess the construct validity of the 20 items of the research instrument. EFA was performed to identify and confirm the underlying structure of the items. Initially the suitability for the data for factor analysis was explored [8].

The EFA results are shown in Table I. Based on the sample of 101 respondents; the 20 items of the MCS were subjected to the EFA using SPSS version 18. The 20 items loaded onto four factors with the factor loadings greater than 0.6 above. The Kaiser-Meyer Olkin of Sample Adequacy (KMO) value was 0.87 , exceeding the recommended value of 0.6 (Kaiser, 1974) which indicate an adequate sample. The Bartletts's Test of Sphericity for the 20 items correlation matrix was highly significant $(\mathrm{p}<0.000)$ reached statistical significance, supporting the factorability of the correlation matrix (Bartlett, 1954). An eigenvalue of 1.0 was set as the minimum criterion for identifying a factor and used as a cutoff value for 
extraction. The results of the analysis indicated the present of only the expected four factors (a scree plot confirmed this number of factors) show the items loaded on each construct $[8]$.

TABLE I: PSYCHOMETRIC PROPERTIES OF THE FOUR DIMENSIONS OF THE MCS INVENTORY, 2012

\begin{tabular}{|c|c|c|c|c|c|c|c|c|c|}
\hline \multirow{2}{*}{$\frac{\text { CODE }}{\text { TEI.I }}$} & \multirow{2}{*}{$\begin{array}{l}\text { KKY VARikis } \\
\text { My manager receives decision from the top } \\
\text { management and announces it to thesubordinates. }\end{array}$} & \multicolumn{4}{|c|}{ LoADRNE } & \multirow{2}{*}{$\frac{\text { MEAN }}{3.97}$} & \multirow{2}{*}{$\frac{\text { ST.Jw }}{1.034}$} & \multirow{2}{*}{$\begin{array}{c}\text { MSA } \\
.908\end{array}$} & \multirow{2}{*}{$\frac{a}{.884}$} \\
\hline & & .758 & -.257 & -.168 & .057 & & & & \\
\hline TEL2 & $\begin{array}{l}\text { My manager makes his/her own decision and } \\
\text { announces it to thesubordinates. }\end{array}$ & .788 & -.287 & -.191 & .078 & 4.35 & .818 & & \\
\hline TEL3 & $\begin{array}{l}\text { My manager expects thesubondinates to carry tasks } \\
\text { given by him/her withont any questions. }\end{array}$ & .838 & -.183 & -.098 & .079 & 3.94 & .835 & & \\
\hline THLA & $\begin{array}{l}\text { My manager only accepts questions concerning how } \\
\text { work is to be done. }\end{array}$ & .741 & -.215 & -.350 & .028 & 3.97 & .793 & & \\
\hline TEI5 & $\begin{array}{l}\text { My manager entertains any inquiries questioning the } \\
\text { desirability of thedecision that has been madeby the } \\
\text { top managementor him/her }\end{array}$ & -.788 & .324 & .206 & -.027 & 3.95 & .841 & & \\
\hline THL 6 & My manager employs a downward commnnication. & .826 & -.248 & -.245 & .153 & 4.15 & .888 & & \\
\hline SEL7 & $\begin{array}{l}\text { My manager persuades thesubordinates of the } \\
\text { desirability of decision madeby the top management } \\
\text { or him/her. }\end{array}$ & .112 & .007 & .170 & .854 & 4.00 & 906 & .833 & .894 \\
\hline SELS & $\begin{array}{l}\text { My manager enconrages inquiries from subordinates } \\
\text { concerning clarification of the decision being made. }\end{array}$ & .014 & .025 & .033 & .879 & 4.10 & .884 & & \\
\hline Ste. 9 & $\begin{array}{l}\text { My manager openly meets any inquiries with } \\
\text { persuasivecofunterarguments and justifications. }\end{array}$ & .101 & -.016 & -.048 & .850 & 4.05 & .910 & & \\
\hline SEL.10 & $\begin{array}{l}\text { My manager shows concerns towards subordinate's } \\
\text { satisfiction with the decision that he/shemakes. }\end{array}$ & .033 & .083 & .024 & .888 & 3.90 & .954 & & \\
\hline CON11 & $\begin{array}{l}\text { My manager only makes final decisions after heishe } \\
\text { has discussed it with thesubordinates. }\end{array}$ & -.181 & .337 & .720 & .175 & 3.77 & .811 & .894 & .905 \\
\hline CON12 & $\begin{array}{l}\text { My manager always makes decisions based on the } \\
\text { needs of both employees and organization. }\end{array}$ & -.369 & .482 & .645 & -.004 & 4.07 & .886 & & \\
\hline CON13 & My manager enconrages a two-way commnnication. & -.248 & .371 & .761 & .043 & 3.92 & .987 & & \\
\hline CON14 & $\begin{array}{l}\text { My manager always explores theadvantages and } \\
\text { disadvantages of various options beforemakingany } \\
\text { decisions. }\end{array}$ & -.537 & .206 & .683 & .047 & 4.10 & 1.025 & & \\
\hline CON15 & $\begin{array}{l}\text { My manager always explores theadvantages and } \\
\text { disadvantages ofvarions options before makingany } \\
\text { decisions. }\end{array}$ & -.278 & .522 & .653 & .008 & 3.82 & 9.63 & & \\
\hline J016 & $\begin{array}{l}\text { My manager always delegrites decision-making to the } \\
\text { subordinates. }\end{array}$ & -159 & .798 & .335 & .015 & 3.49 & 1.016 & .892 & .869 \\
\hline J017 & $\begin{array}{l}\text { My manager sets parameters and lets subordinates } \\
\text { makedecisions. }\end{array}$ & -.346 & .788 & .271 & -.051 & 3.58 & .886 & & \\
\hline J018 & $\begin{array}{l}\text { Decisions beingmadeare based on the majority } \\
\text { opinionafter open discussions. }\end{array}$ & -.362 & .787 & .193 & .080 & 3.47 & 1.035 & & \\
\hline J019 & $\begin{array}{l}\text { Decisions can also be made withont my manager's } \\
\text { presence. }\end{array}$ & -.383 & .711 & 320 & -.005 & 3.61 & 8.48 & & \\
\hline J020 & $\begin{array}{l}\text { My manager is concerned with the subordinates' } \\
\text { desirability in decision-making }\end{array}$ & -.295 & .734 & .288 & .117 & 3.63 & 8.45 & & \\
\hline
\end{tabular}

Among these 20 items, the factor analysis extracted four factors which explained $70.67 \%$ of the variance, the factor loadings were all greater than 0.60 and the cross loadings were minimal. The percentages of variance explained for each factor were $37.78 \%, 20.46 \%, 7.44 \%$, and $5.00 \%$ respectively. The eigenvalues of the first four factors were $7.56,4.10,1.49$, and 1.01 respectively. Four factors or domains were retained. As for the test of uni dimensionality, high factor loadings above the threshold of 0.4 considered practically significant if sample of respondent $>350$. High MSA $>0.5$ indicates the data are low in multicollinearity, and this is suitable for the factor analysis [19]. In the light of the rotated component matrix, the model confirmed the presences of four MCS having 6 items were allocated to the first factor named Tell. The second factor consists of 4 items, named Sell. The third factor, with 5 items, named consult. The last factor included 5 items and was named Join. This analysis confirmed the final selection of the 20 items for the scale. All of the items in MCS variables have exhibit value ranging from 0.80 to 0.90 for cronbach alpha.

Convergent Validty: Further to the construct validity test using the factor analysis (between scales) another factor analysis using the within scale was conducted to test the convergent validity. Convergent validity was carried out through a within factor in order to obtain a more in-depth judgment of the dimensionality of the construct under study [13]. Convergent validity was assessed based on the factor loading, composite reliability (CR), and average variance extracted (AVE) [20]. Table II summarizes the results of internal reliability and convergent validity for the four constructs of MCS. The factor loading for all items in this study exceeded the recommended level of 0.6 [21]. CR which depicts the degree to which the construct indicators indicate 
the latent construct, ranged from 0.890 to 0.930 exceeding the recommended level of 0.7 which was suggested by [22]. The AVE which reflects the overall amount of variance in the indicators accounted for by the latent construct, were in the range between 0.658 and 0.726 , exceeding the recommended level of 0.5 as suggested by [13]. Hence, the analysis provides support for convergent validity.

\begin{tabular}{|c|c|c|c|c|}
\hline \multicolumn{5}{|c|}{ TABLE II: CONVERGENT VALIDITY } \\
\hline CONSTRUCT & ITEM & $\begin{array}{c}\text { ITEM } \\
\text { LOADING }\end{array}$ & AVE & $\mathrm{CR}$ \\
\hline \multirow[t]{6}{*}{ Tell } & Tel1 & 0.803 & 0.658 & 0.920 \\
\hline & Tel2 & 0.831 & & \\
\hline & Tel3 & 0.844 & & \\
\hline & Tel4 & 0.789 & & \\
\hline & Tel5 & 0.759 & & \\
\hline & Tel6 & 0.839 & & \\
\hline \multirow[t]{4}{*}{ Sell } & Sel7 & 0.780 & 0.677 & 0.893 \\
\hline & Sel8 & 0.846 & & \\
\hline & Sel9 & 0.837 & & \\
\hline & Sel10 & 0.826 & & \\
\hline \multirow[t]{5}{*}{ Consult } & Con11 & 0.812 & 0.726 & 0.930 \\
\hline & Con12 & 0.841 & & \\
\hline & Con13 & 0.850 & & \\
\hline & Con14 & 0.891 & & \\
\hline & Con 15 & 0.863 & & \\
\hline \multirow[t]{5}{*}{ Join } & Jo16 & 0.870 & 0.657 & 0.905 \\
\hline & Jo17 & 0.881 & & \\
\hline & Jo18 & 0.760 & & \\
\hline & Jo19 & 0.815 & & \\
\hline & Jo20 & 0.714 & & \\
\hline
\end{tabular}

Note: $\mathrm{CR}=$ Composite reliability, $\mathrm{AVE}=$ Average Variance Extracted, Scale used was a 6 point Likert scale.

TABLE III: DISCRIMINANT VALIDITY

\begin{tabular}{|l|c|c|c|c|}
\hline Constructs & Join & Consult & Sell & Tell \\
\hline Join & 0.811 & & & \\
\hline Consult & 0.708 & 0.823 & & \\
\hline Sell & 0.186 & 0.387 & 0.823 & \\
\hline Tell & -0.628 & -0.699 & -0.205 & 0.811 \\
\hline
\end{tabular}

Note: Diagonals represents the square root of the average variance extracted while the other entries represent the correlations

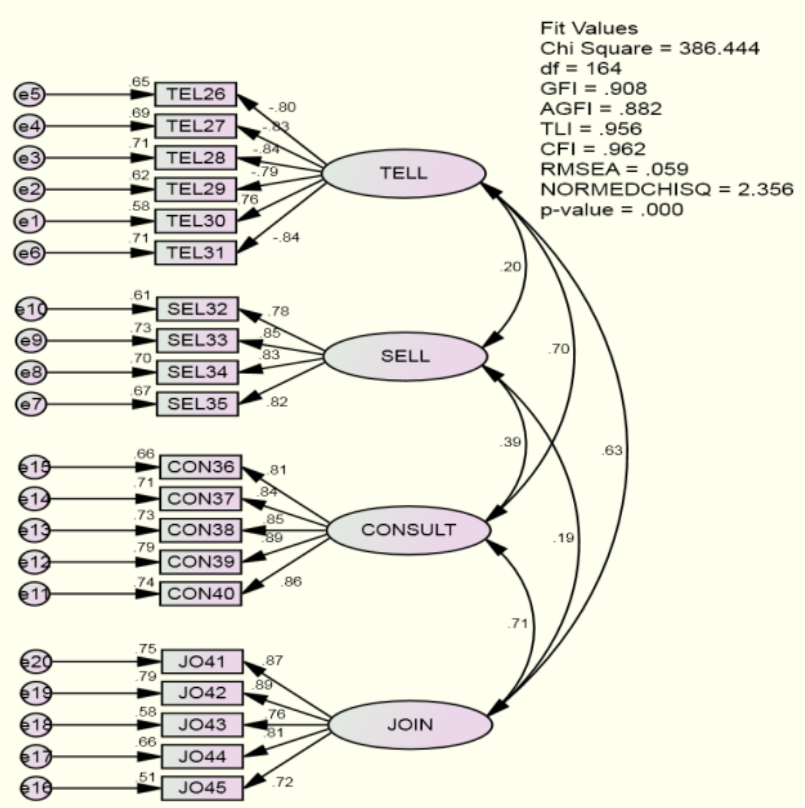

Fig. 1. Full measurement model for MCS
Next, discriminant validity which measures the degree to which the measures of different concepts are distinct was examined. Discriminant validity can be examined by comparing the correlations between constructs and the square root of the variance extracted for a construct [21]. Table III illustrated that the correlations for each construct was less than the square root of the AVE by the indicators measuring that construct indicating that the measure had adequate discriminant validity. In summary the measurement model demonstrated adequate reliability, convergent validity, and discriminant validity.

To assess the fit of the measurement model, several indices were generated, (see Fig. 1) the normed chi square was 2.356 which was lower than 3 [23]. The goodness-of-fit index (GFI $=0.908)$, the comparative fit indices ( $\mathrm{CFI}=0.962)$ and the root mean square error of approximation (RMSEA $=0.059$ ) was lower than 0.08 [14]. Thus, from the above discussion, it can be concluded that the measurement model fit the data well.

\section{CONCLUSION}

The current study provides greater detail as to the measurement of MCS constructs that will be used in the original study later in Malaysia. Though Richmond \& McCroskey [5] have identified four communication styles namely, Tell, Sell, Consult, and Join, they have not highlighted the measurement of the instrument they used to measure these four dimensions or management communication styles. Having developed this management communication styles measurement, the authors believe that such an instrument is a step forward towards effectively measuring management communication styles namely, Tell, Sell, Consult, and Join. The significance of this measurement lies in the fact that departing from the majority of the existing research that focuses on the importance of communication styles on organizational conflict, commitment, job satisfaction and other variables, this research is about the instrument used to measure the above-mentioned styles. Hence, this paper presents a valid and reliable instrument that measures the different management communication styles in the Malaysian context [8]. The concept of MCS offers substantial promise as a topic for further research. An additional particular importance for future research is the impact of MCS on organizational conflict, organizational commitment, and job satisfaction. By addressing and measuring specific MCS that imposed on managers from the top management or chosen by the managers, we are able to identify the styles of decision-making and communication traits of an individual that, when applied in the organizational context, will improve the relationship between supervisor and the subordinates as well as achieve functional and constructive conflict at the workplace, commitment, and job satisfaction. 


\section{APPENDIX: QUESTIONNAIRE ITEMS}

\begin{tabular}{|c|c|c|}
\hline Construct & Items & Source \\
\hline \multirow[t]{6}{*}{ Tell } & $\begin{array}{l}\text { Tel1=My manager receives decision from } \\
\text { the top management and announces it to } \\
\text { subordinates. }\end{array}$ & $\begin{array}{l}\text { Richmond } \\
\text { and } \\
\text { McCroskey } \\
(2009)\end{array}$ \\
\hline & $\begin{array}{l}\text { Tel2= My manager makes his/her own } \\
\text { decision and announces it to the } \\
\text { subordinates }\end{array}$ & \\
\hline & $\begin{array}{l}\text { Tel3=My manager expects me to carry out } \\
\text { tasks given by him/her without any } \\
\text { questions. }\end{array}$ & \\
\hline & $\begin{array}{l}\text { Tel4=My manager only accepts questions } \\
\text { concerning how work is to be done. }\end{array}$ & \\
\hline & $\begin{array}{l}\text { Tel5 = My manager entertains any } \\
\text { inquiries on the desirability of the decision } \\
\text { that has been made by the top } \\
\text { management or him } / \text { her. }\end{array}$ & \\
\hline & $\begin{array}{l}\text { Tel6=My manager employs a downward } \\
\text { communication. }\end{array}$ & \\
\hline \multirow[t]{4}{*}{ Sell } & $\begin{array}{l}\text { Sel7= My manager persuades the } \\
\text { subordinates of the desirability of } \\
\text { decisions made by the top management or } \\
\text { him/her. }\end{array}$ & $\begin{array}{l}\text { Richmond } \\
\text { and } \\
\text { McCroskey } \\
(2009)\end{array}$ \\
\hline & $\begin{array}{l}\text { Sel8=My manager encourages inquiries } \\
\text { from subordinates concerning } \\
\text { clarification of the decision being made. }\end{array}$ & \\
\hline & $\begin{array}{l}\text { Se19=My manager encourages inquiries } \\
\text { from subordinates concerning } \\
\text { clarification of the decision being made. }\end{array}$ & \\
\hline & $\begin{array}{l}\text { Sel10=My manager shows concerns } \\
\text { towards subordinate's satisfaction with } \\
\text { the decision that he/she makes. }\end{array}$ & \\
\hline \multirow[t]{5}{*}{ Consult } & $\begin{array}{l}\text { Con } 11=\text { My manager only makes final } \\
\text { decisions after he/she has discussed it with } \\
\text { the subordinates. }\end{array}$ & $\begin{array}{l}\text { Richmond } \\
\text { and } \\
\text { McCroskey }\end{array}$ \\
\hline & $\begin{array}{l}\text { Con } 12=\text { My manager always makes } \\
\text { decisions based on the needs of both } \\
\text { employees and organization. }\end{array}$ & (2009) \\
\hline & $\begin{array}{l}\text { Con } 13=\text { My manager always makes sure } \\
\text { that the decisions make by the top } \\
\text { management or him/her will conserve the } \\
\text { well-being of the subordinates. }\end{array}$ & \\
\hline & $\begin{array}{l}\text { Con } 14=\text { My manager encourages a } \\
\text { two-way communication. }\end{array}$ & \\
\hline & $\begin{array}{l}\text { Con } 15=\text { My manager always explores the } \\
\text { advantages and disadvantages of various } \\
\text { options before making any decisions. }\end{array}$ & \\
\hline \multirow[t]{5}{*}{ Join } & $\begin{array}{l}\text { Jo16=My manager always delegates } \\
\text { decision-making to the subordinates. }\end{array}$ & $\begin{array}{l}\text { Richmond } \\
\text { and } \\
\text { McCroskey }\end{array}$ \\
\hline & $\begin{array}{l}\text { Jo17=My manager sets parameters and } \\
\text { lets subordinates make decisions. }\end{array}$ & (2009) \\
\hline & $\begin{array}{l}\text { Jo } 18=\text { Decisions being made are based on } \\
\text { the majority opinion after open } \\
\text { discussion. }\end{array}$ & \\
\hline & $\begin{array}{l}\text { Jo19=Decisions can also be made without } \\
\text { my manager's presence. }\end{array}$ & \\
\hline & $\begin{array}{l}\mathrm{J} 20=\text { My manager is concerned with the } \\
\text { subordinates' desirability in } \\
\text { decision-making. }\end{array}$ & \\
\hline
\end{tabular}

\section{ACKNOWLEDGMENT}

Authors would like to than R. A. Aziz, M. Muhammad, and I. Abu-Jarad for Table 1: Psychometric properties of the our dimentsion of the MCSs inventory (2012)

\section{REFERENCES}

[1] V. P. Richmond and J. C. McCroskey, Organizational Communication for Survival: Making Work, Work. (10th ed.), 2009.

[2] V. P. Richmond, J. C. McCroskey, L. M. Davis, and K. A. Koontz, "Perceived power as a mediator of management communication style and employee satisfaction: A preliminary investigation," Communication Quarterly, vol. 28, pp. 37-46, 1980.
[3] L. L. McCroskey, J. C. McCroskey, and V. P. Richmond, "Applying organizational orientations theory to employees of profit and non-profit organizations," Communication Quarterly, vol. 53, pp. 21-40, 2005.

[4] S. Parayitam and R. S. Dooley, "The relationship between conflict and decision outcomes: Moderating effects of cognitive-and affect-based trust in strategic decision-making teams," International Journal of Conflict Management, vol. 18, pp. 42-73, 2007.

[5] V. P. Richmond and J. C. McCroskey, "Management Communication Style, Tolerance for Disagreement, and Innovatives as predictors fo employee satisfaction: A comparison of single-factor, two-factor, and multiple factor approaches," Communication Yearbook, vol. 3, pp. 359-373, 1979.

[6] R. Tannenbaum and W. H. Schmidt, How to choose a leadership pattern, Institute of industrial relations, 1958.

[7] P. J. Sadler, "Leadership style, confidence in management, and job satisfaction," The Journal of Applied Behavioral Science, vol. 6, pp. 3-19, 1970.

[8] R. A. Aziz, M. Muhammad, and I. Abu-Jarad, "Management communication styles: conceptualization and scale development," in Proc. of Conference on Innovation Management and Technology Research (ICIMTR), pp. 28-32, 2012.

[9] T. R. Hinkin, "A review of scale development practices in the study of organizations," Journal of Management, vol. 21, pp. 967-988, 1995.

[10] T. R. Hinkin, "A brief tutorial on the development of measures for use in survey questionnaires," Organizational research methods, vol. 1, pp. 104-121, 1998.

[11] A. Cohen, R. DeVore, and C. Schwab, "Convergence rates of best N-term Galerkin approximations for a class of elliptic sPDEs," Foundations of Computational Mathematics, vol. 10, pp. 615-646, 2010.

[12] J. F. Hair, W. C. Black, B. J. Babin, and R. E. Anderson, Multivariate Data Analysis: A Global Perspective, 7th ed. Upper Sadler River, NJ: Pearson Education, Inc., 2010.

[13] J. Pallant, "SPSS survival manual," 4 ed. New York, NY: McGraw Hill, 2010.

[14] B. M. Byrne, Structural Equation Modelling with AMOS: Basic concepts, applications, and programming, 2nd ed.: Taylor and Francis Group, 2010.

[15] C.-H. Chang, "The Influence of User's Trait on Public e-Service Usage: A Self-Service Technology Perspective," Asian Social Science, vol. 7, pp. 3, 2011

[16] G. A. Churchill Jr, "A paradigm for developing better measures of marketing constructs," Journal of Marketing Research, pp. 64-73, 1979.

[17] J. Nunnally, Psychometric methods, New York: McGraw, 1978.

[18] P. Muchinsky, "Enhancing industrial/organizational psychology: a challenging mandate at the dawn of the 21st century," Japanese Association of Industrial/Organizational Psychology Journal, vol. 20, pp. 1-27, 2006.

[19] P. R. Jackson, T. D. Wall, R. Martin, and K. Davids, "New measures of job control, cognitive demand, and production responsibility," Journal of Applied Psychology, vol. 78, pp. 753, 1993.

[20] C. Fornell and D. F. Larcker, "Structural equation models with unobservable variables and measurement error: Algebra and statistics," Journal of Marketing Research, pp. 382-388, 1981.

[21] W. W. Chin, A. Gopal, and W. D. Salisbury, "Advancing the theory of adaptive structuration: The development of a scale to measure faithfulness of appropriation," Information Systems Research, vol. 8, pp. 342-367, 1997.

[22] D. Gefen, D. W. Straub, and M.-C. Boudreau, "Structural equation modeling and regression: Guidelines for research practice," 2000.

[23] R. P. Bagozzi, Y. Yi, and L. W. Phillips, "Assessing construct validity in organizational research," Administrative science quarterly, pp. 421-458, 1991.

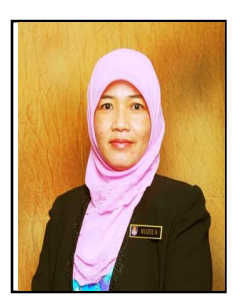

Rozilah Abdul Aziz was born in Kuala Lumpur, Malaysia. She is a postgraduate student at Universiti Teknologi MARA, Shah Alam and currently conducting a doctoral research in the field of Organizational Communication. Rozilah has obtained her MSc. in Corporate Communication, Universiti Putra Malaysia (UPM) and BBA in Business Administration, Western Michigan University, USA. She is currently a senior lecturer at the Faculty of Business Management in Universiti Teknologi MARA, Shah Alam. Her areas of interest include Organizational Communication, Human Communication, Organizational Behavior and Personality Development. 


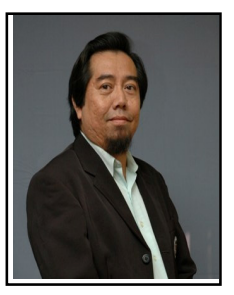

Mokhtar Muhammad is a Phd holder in Malaysian Political History from University Malaya; MSc in Jounalism and Mass Communication, Iowa State University, BSc in Journalism, University of Colorado; and Diploma in Mass Communication (Journalism) Institut Teknologi MARA (ITM). He is currently a professor at Journalism Programme in Universiti Teknologi MARA (UiTM). He is also the Director, Institute of Journalism Studies, Faculty of Communication and Media Studies, UiTM. Prof. Dr. Mokhtar areas of expertise and research include, Journalism; Communication; Social Science History; sociological Studies of Journalism; News-Editorial Writing Journalism; Studies of the Media; Culture and Society; Communication and Change, Organizational Communication; Human Communication; International Communication; International Relations; Global Contemporary and Political Studies.

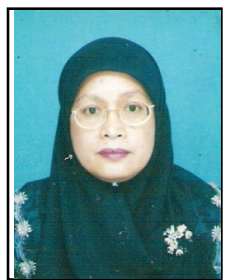

Norlida has obtained his $\mathrm{PhD}$ in International Business Management, from Universiti Sains Malaysia; MBA from Governer State University of Illinois, USA; BBA, Ohhio University Athens, USA; and Diploma in Food Technology, Insitut Teknologi MARA (ITM). She is currently a Deputy Dean at the Faculty of Business Management in Universiti Teknologi MARA. Dr. Norlida is an associate member of Malaysian Institute of Human Resource Management. Her areas of expertise include, but not limited to International Management, Organizational Behavior, Human Resource Management, Principal of Mangement, Communication. Her paper entitled "The Impct of Communicatin to the Performance of International Jiont Ventures Abroad: Case of Malaysia" has won the Best Award Paper at the UNITEN International Business Management Conference (2007) 